\title{
Kinetics and mechanism of electron transfer to pyridinium chlorochromate (VI) from sulfur containing amino acid, L-cysteine in aqueous and micellar media
}

\author{
Sadhana Senapati ${ }^{1}$, Smrutiprava $\operatorname{Das}^{2}$, P. Mohanty ${ }^{1}$ A.K. Patnaik ${ }^{3 *}$ \\ ${ }^{1}$ PG Department of Chemistry, Utkal University, Vani Vihar, Bhubaneswar-751004, Orissa, India \\ ${ }^{2}$ PG Department of Chemistry, Ravenshaw Uiversity, Cuttack-753003, Orissa, India \\ ${ }^{3}$ PG Department of Chemistry, Khallikote College, Berhampur- 76001, Orissa, India \\ *Corresponding author: e-mail: ajaypattanaik_kumar@yahoo.co.in
}

\begin{abstract}
The electron transfer reaction of L-cysteine (RSH) with pyridinium chlorochromate (PCC) has been studied spectrophotometrically over the range $2.0 \leq 10^{3}[\mathrm{RSH}] \leq 6.0 ; 0.01 \leq\left[\mathrm{H}^{+}\right] \leq 0.2 ; 298 \leq \mathrm{T} \leq 318 \mathrm{~K}$ and $\mathrm{I}=0.3 \mathrm{~mol} \mathrm{dm}^{-3}\left(\mathrm{NaClO}_{4}\right)$. The electron transfer reaction has also been carried out in the presence of anionic, cationic and neutral micelle. The reaction in acid medium is strongly catalyzed by changing $[\mathrm{SDS}]_{\mathrm{T}}$ (sodium dodecyl sulfate) up to $3 \times 10^{-2} \mathrm{~mol} \mathrm{dm}^{-3}$, beyond this concentration of SDS, the rate is retarded. The cationic and neutral micelle has a small effect on the rate. $\Delta H^{\ddagger}\left(\mathrm{kJ} \mathrm{mol}^{-1}\right)$ and $\Delta S^{\ddagger}\left(\mathrm{JK}^{-1} \mathrm{~mol}^{-1}\right)$ values for the $\mathrm{k}_{1}$ and $\mathrm{k}_{2}$ paths are $30.20 \pm 0.25,-159.65 \pm 0.83$ and $29.60 \pm 0.62,-127.09 \pm 2.17$, respectively. The negative activation entropy is indicative of the ordered transition state for the electron transfer reaction. Formation of 2-amino-3-(2-amino-2-carboxy-ethyl) disulfanyl-propanoic acid as product is strongly supported by IR spectra.
\end{abstract}

Keywords: kinetics mechanism, electron transfer, pyridinium chlorochromate, cysteine, micellar media.

\section{INTRODUCTION}

In recent years there has been a great upsurge of interest on mechanistic studies of reactions of amino acids with transition metal complexes, due to their biological relevance $^{1-8}$. Amino acids are important biomolecules which are not only building blocks of proteins but they also function as chemical messengers in bringing about communication between cells. This prompted us to undertake the present study which includes interaction of sulfur containing amino acid, cysteine with $\mathrm{Cr}(\mathrm{VI})$ in the form of pyridinium chlorochromate (PCC). L-cysteine is an important amino acid which has three active donor sites of $\mathrm{O}, \mathrm{N}$ and $\mathrm{S}$. It would be interesting to know which active site of cysteine will interact with $\mathrm{Cr}$ (VI) during the electron transfer process. Since most biological processes occur at interfaces, structure, dynamics and the reactivity of biomolecules differ at an interface than those observed in the bulk. Keeping this in view the present study was carried out both in the aqueous and micellar media.

\section{EXPERIMENTAL}

\section{Raw materials}

Analytical grade chemicals were used. Pyridinium chlorochromate (PCC) was synthesised as reported earlier'. Ionic strength was maintained at $\mathrm{I}=0.3 \mathrm{~mol} \mathrm{dm}^{-3}$ by using the freshly prepared $\mathrm{NaClO}_{4}$ solution. Solutions of different concentrations were prepared by proper dilution of the stock solution, fresh solutions were used for kinetic measurements. The strength of stock $\mathrm{NaClO}_{4}$ solution was estimated by a combined ion-exchange alkalimetric procedure. The resin Dowex $50 \mathrm{~W}$ X8 $\left(\mathrm{Na}^{+}\right.$ form) was used for ion-exchange experiments.

Fresh solutions were prepared using double distilled water in an all-quartz distillation apparatus containing $\mathrm{KMnO}_{4}$ solution.
Sodium dodecyl sulphate (SDS), N-cety- $N, N, N$ trimethyl Ammonium Bromide (CTAB) and the commercial surfactant, Triton X-100 were used as anionic, cationic and neutral micelles, respectively. The stock micellar solution of the strength of $1.0 \mathrm{~mol} \mathrm{dm}^{-3}$ was prepared by dissolving the required amount of the surfactant in the double distilled water. The acetic acid used was purified by the reported procedure ${ }^{\mathbf{1 0}}$.

\section{Kinetic measurements}

The kinetics of the reaction between cysteine and PCC in the aqueous and micellar medium were studied spectrophotometrically under the pseudo-first order conditions with an excess of cysteine using a CECIL 7200 (UK) UV-Visible spectrophotometer with a thermostatic bath for temperature control with an accuracy of $\pm 0.1^{\circ} \mathrm{C}$. The progress of the reaction was monitored by the following decrease in absorbance at $425 \mathrm{~nm}$ with time using a conventional mixing technique. $\mathrm{A}_{\propto}$ was measured after the completion of the reaction (approximately after 24 hours of mixing) when the absorbance became almost constant.

The plot of $\ln \left(A_{t}-A_{\infty}\right)$ versus $t$ was found to be linear as indicated in the equation (1).

$\ln \left(\mathrm{A}_{\mathrm{t}}-\mathrm{A}_{\propto}\right)=\ln \left(\mathrm{A}_{0}-\mathrm{A}_{\propto}\right)-\mathrm{k}_{\mathrm{obs}} . \mathrm{t}$

Where $A_{t}$ and $A_{\propto}$ are absorbances of the reaction mixture at time $t$ and at equilibrium respectively. The correlation coefficients $\left(\mathrm{R}^{2}\right)$ of the plots used to determine $\mathrm{k}_{\mathrm{obs}}$ were found to be 0.99 . The pseudo-first order rate constant $\left(\mathrm{k}_{\mathrm{obs}}\right)$ was calculated by the least squares method from the above relationship. The redox reactions were followed for about 3 half lives. The reported rate data represent as an average of duplicate runs were reproducible to within $\pm 3 \%$. 


\section{Stoichiometry and identification of product}

The reaction mixture containing $\mathrm{PCC}$ and cysteine in the molar ratio $1: 10$ was warmed at $318 \mathrm{~K}$ to complete the reaction. The unreacted chromium (VI) and product chromium (III) were estimated ${ }^{\mathbf{1 1}}$. From the above experimental findings it was observed that 2 moles of PCC reacted with 6 moles of cysteine to generate disulfanylpropionic acid (cystine) and $\mathrm{Cr}^{3+}(\mathrm{aq})$. The stoichiometry of the above reaction is explained by equation (2). 6 Cysteine $+2 \mathrm{PCC} \rightarrow 3$ Cystine $+2 \mathrm{Cr}\left(\mathrm{H}_{2} \mathrm{O}\right)_{6}{ }^{+3}$

In order to get the reaction product, $\mathrm{PCC}(0.2 \mathrm{~mol})$, cysteine $(0.02 \mathrm{~mol})$, were mixed at $\left[\mathrm{H}^{+}\right]=0.2 \mathrm{~mol} \mathrm{dm}^{-3}$. The volume of the made solution was $50 \mathrm{ml}$. The reaction mixure was warmed for a quick completion of the reaction. The mixure was refrigerated over night. A crystalline product was formed, it was washed with diethylether and the product was dried in a desiccator. The yield of the product was $70 \%$. The FTIR spectra of cysteine and the product (Fig. 1) were recorded with a Perkin Elmer (UK) FTIR spectrophotometer. A broad strong peak around at $3564 \mathrm{~cm}^{-1}$ in the product may be assigned to stretching vN - H $\left(-\mathrm{NH}_{3}{ }^{+}\right)$, as compared to $3177 \mathrm{~cm}^{-1}$ and $2962 \mathrm{~cm}^{-1}$ in L-cysteine. The shifting to higher frequency is probably due to an association of water molecule with the product. Two $\mathrm{NH}_{3}{ }^{+}$bending bands and a strong absorption peak of caboxylate ion are mixed up and a broad band is observed at $1613 \mathrm{~cm}^{-1}$ in the product compared to 1586,1544 , $1423 \mathrm{~cm}^{-1}$ peaks in L-cysteine. The overtone band at 2079 $\mathrm{cm}^{-1}$ in L-cysteine is shifted to $2017 \mathrm{~cm}^{-1}$ in the product, weak band at $2551 \mathrm{~cm}^{-1}$ in cysteine due to S-H stretching is absent in the product suggesting that cysteine dimerises to disulfanyl-propanoic acid having S-S linkage. Strong and broad peak of $1093 \mathrm{~cm}^{-1}$ and a sharp peak of $630 \mathrm{~cm}^{-1}$ in the product correspond to $1063 \mathrm{~cm}^{-1}$ and $692 \mathrm{~cm}^{-1}$ in the cysteine (I) and is due to free $\mathrm{NH}_{2}$ twisting and rocking $^{\mathbf{1 2}}$. Formation of disulfanyl-propanoic acid (II) as product is strongly supported by the IR spectra.<smiles>NC(CS)C(=O)O</smiles>

(I)

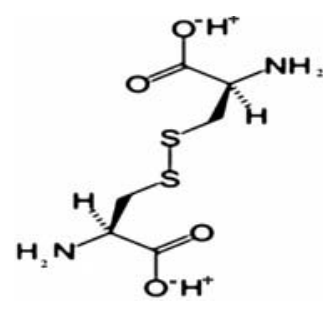

(II)
(Cysteine Substrate)

(Product disulfanyl-propanoic acid)

\section{RESULTS AND DISCUSSION}

The electron transfer reaction between L-cysteine and PCC has been studied over the range $2.0 \leq 10^{3}$ [cysteine $_{\mathrm{T}}$ $\leq 6.0 ; 0.01 \leq\left[\mathrm{H}^{+}\right] \leq 0.2,298 \mathrm{~K} \leq \mathrm{T} \leq 318 \mathrm{~K}$ and $\mathrm{I}=0.3$ mol dm ${ }^{-3}\left(\mathrm{NaClO}_{4}\right)$.

The UV-VIS spectral scan (Fig. 2) of the reaction mixture of L-cysteine and PCC over the range $200 \leq \lambda(\mathrm{nm})$ $\leq 600$ shows shifting of absorption maxima from $350 \mathrm{~nm}$ to $425 \mathrm{~nm}$, indicating the formation of an intermediate species between cysteine and PCC. The said intermediate was found to decay with the increasing time. After a long interval (approximately $24 \mathrm{hrs}$ ) the peak at $425 \mathrm{~nm}$ vanished completely and two new peaks appeared (Fig 2) at

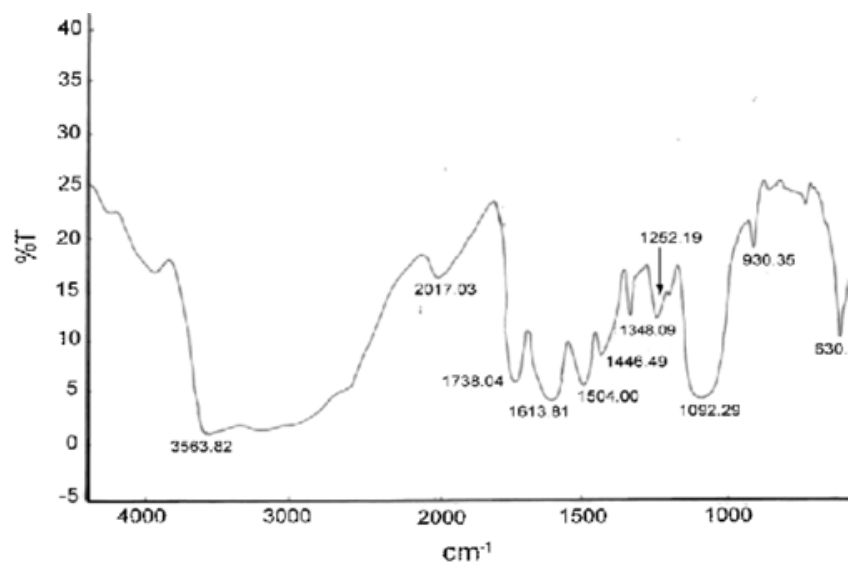

Figure 1. The FTIR spectra of the product (disulphanyl propanoic acid)

$410 \mathrm{~nm}$ and $566 \mathrm{~nm}$ which corresponded to the spectrum of $\mathrm{Cr}\left(\mathrm{H}_{2} \mathrm{O}\right)_{6}{ }^{3+}{ }^{13}$.

The $\mathrm{k}_{\mathrm{obs}}$ of the above reactions are listed in Table 1. Plots of $\mathrm{k}_{\mathrm{obs}}$ versus L-cysteine were linear with finite positive intercepts. The rate of the reaction was also seen to increase with increasing $\left[\mathrm{H}^{+}\right]^{2}$ at constant [cysteine] (Fig. 3).

The pseudo - first order rate constants $\left(10^{4} \mathrm{k}_{\mathrm{obs}}\left(\mathrm{s}^{-1}\right)\right.$ $=6.46 \pm 0.29)$ at $303 \mathrm{~K}$ were almost not affected by varying $[\mathrm{PCC}]$ in the range from $3 \times 10^{-3}$ to $8 \times 10^{-3} \mathrm{~mol} \mathrm{dm}^{-3}$ at $\left[\mathrm{H}^{+}\right]=0.05 \mathrm{~mol} \mathrm{dm} \mathrm{dm}^{-3}$ indicating the fact that the reaction is the first order in $[\mathrm{Cr}(\mathrm{VI})]_{\mathrm{T}}$.

In order to know what type of species are involved in the rate determining step, the reaction was investigated by changing the ionic strength of the medium in the range 0.1 to $0.5 \mathrm{~mol} \mathrm{dm}^{-3}$ keeping $[\mathrm{PCC}]_{\mathrm{T}}=5.0 \times 10^{-4}$ and [cysteine $_{\mathrm{T}}=4.0 \times 10^{-3}$ constant at $\left[\mathrm{H}^{+}\right]=0.05 \mathrm{~mol} \mathrm{dm}^{-3}$. $10^{4} \mathrm{k}_{\mathrm{obs}}\left(\mathrm{s}^{-1}\right)=6.63 \pm 0.09$, did not change appreciably. This indicates that probably charged and uncharged species are involved in the rate determining step.

The effect of relative permittivity was studied at $303 \mathrm{~K}$ by varying aqueous [acetic acid] $20 \%$ to $70 \%$, when [PCC] $=$ $5.0 \times 10^{-4}$, [Complex] $=4.0 \times 10^{-3}, \mathrm{I}=0.3 \mathrm{~mol} \mathrm{dm}^{-3} 104$ $\mathrm{k}_{\mathrm{obs}}\left(\mathrm{s}^{-1}\right)$ changed from 6.4 to 22.4 when $\%$ of HAC vary from $\%$ and dielectric constant changed 81.50 to 38.50. This indicates a probable polar character for the transition state as

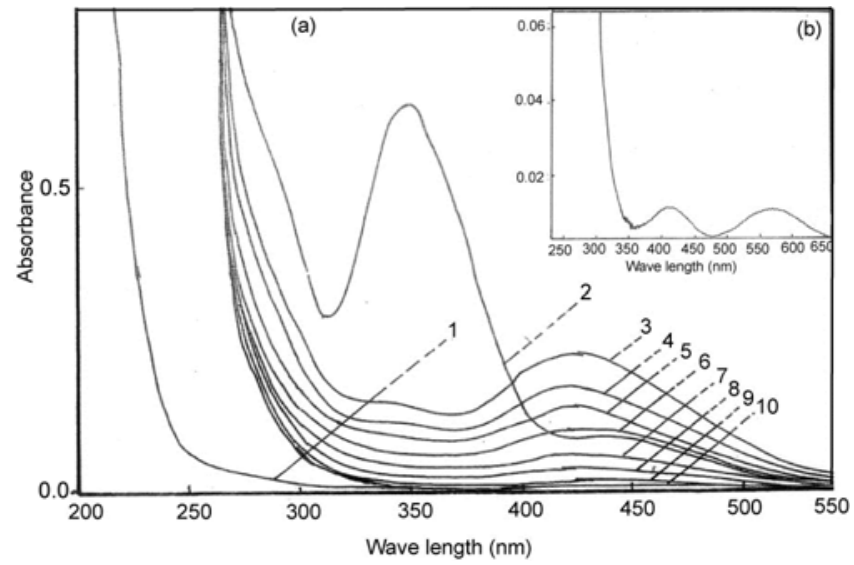

Figure 2. UV-VIS spectral scan of reaction mixture of L-cysteine and PCC, $\left[\mathrm{H}^{+}\right]=0.1 \mathrm{~mol} \mathrm{dm}{ }^{-3}, \mathrm{I}=0.3$ mol dm${ }^{-3}\left(\mathrm{NaClO}_{4}\right)$ at $303 \mathrm{~K}$ (a)(1) [cysteine] $=4$ $\mathrm{X} 10^{-3} \mathrm{~mol} \mathrm{dm}{ }^{-3}$, (2) $[\mathrm{PCC}]=4 \times 10^{-4} \mathrm{~mol} \mathrm{dm}^{-3}$, (3) immediate after mixing, (4) after 15 minutes, (5-9) $\Delta t=5$ minutes, (10) after 2 hours. (b) Inset: Spectral scan after $24 \mathrm{hrs}, 303 \mathrm{~K}$ 
Table 1. Pseudo-first order rate constant (kobs) data at different temperatures $298 \mathrm{~K}-318 \mathrm{~K}$, $[\mathrm{PCC}]=5 \mathrm{x} 10^{-4} \mathrm{~mol} \cdot \mathrm{dm}^{-3}$, I (ionic strength $)=0.3 \mathrm{~mol} \cdot \mathrm{dm}^{-3} \quad\left(\mathrm{NaClO}_{4}\right)$

\begin{tabular}{|c|c|c|c|c|c|c|}
\hline \multirow{2}{*}{$\begin{array}{l}{\left[\mathrm{H}^{+}\right]} \\
\left(\mathrm{mol} \mathrm{dm}{ }^{-3}\right)\end{array}$} & \multirow{2}{*}{$\begin{array}{c}10^{3} \text { [cysteine] } \\
\left(\mathrm{mol} \mathrm{dm}^{-3}\right)\end{array}$} & \multicolumn{5}{|c|}{$10^{4} \mathrm{k}_{\mathrm{obs}}\left(\mathrm{s}^{-1}\right)$} \\
\hline & & $298 K$ & $303 \mathrm{~K}$ & $308 \mathrm{~K}$ & $313 K$ & $318 \mathrm{~K}$ \\
\hline \multirow[t]{4}{*}{0.01} & 2.0 & 2.54 & 3.30 & 4.40 & 5.50 & 6.60 \\
\hline & 3.0 & 2.98 & 4.00 & 5.40 & 7.40 & 9.25 \\
\hline & 4.0 & 3.53 & 4.75 & 6.50 & 9.08 & 11.20 \\
\hline & 6.0 & 4.63 & 6.37 & 8.934 & 12.80 & 16.00 \\
\hline \multirow[t]{4}{*}{0.05} & 2.0 & 6.505 & 7.63 & 8.77 & 9.90 & 11.80 \\
\hline & 3.0 & 6.88 & 8.27 & 9.97 & 12.00 & 14.10 \\
\hline & 4.0 & 7.097 & 8.65 & 10.60 & 13.28 & 15.40 \\
\hline & 6.0 & 7.658 & 9.97 & 13.13 & 17.52 & 21.30 \\
\hline \multirow[t]{5}{*}{0.15} & 2.0 & 9.33 & 12.00 & 15.36 & 19.60 & 24.40 \\
\hline & 3.0 & 14.29 & 16.55 & 19.16 & 22.20 & 25.10 \\
\hline & 4.0 & 17.48 & 19.30 & 21.53 & 24.30 & 25.80 \\
\hline & 5.0 & 19.22 & 21.50 & 24.01 & 26.80 & 29.50 \\
\hline & 6.0 & 21.48 & 24.50 & 27.96 & 31.97 & 35.60 \\
\hline \multirow[t]{4}{*}{0.2} & 2.0 & 11.34 & 15.00 & 20.13 & 27.48 & 33.60 \\
\hline & 3.0 & 14.78 & 19.00 & 25.20 & 31.20 & 39.93 \\
\hline & 4.0 & 19.75 & 23.90 & 29.03 & 35.43 & 41.20 \\
\hline & 6.0 & 25.49 & 31.00 & 37.85 & 46.85 & 54.20 \\
\hline
\end{tabular}

compared to the reactants or an ion-dipolar interaction in the rate determining step. The plot of $\mathrm{k}_{\mathrm{obs}}$ versus $1 / \mathrm{D}$ was linear with a positive slope $\left(\mathrm{R}^{2}=0.99\right)$.

The reaction mixture was mixed with acrylonitrile monomer and kept for $2 \mathrm{hrs}$ in an inert atmosphere. On diluting with methanol, a white precipitate was formed indicating the presence of free radicals in the reaction. However, the blank experiments with each reactant alone in the presence of acrylonitrile did not produce any precipitate.

The reaction rate was measured at five different temperatures $(298 \mathrm{~K}-318 \mathrm{~K})$ with varying substrate concentrations (Table 1) keeping other variables constant. The rate constant $\left(\mathrm{k}_{\mathrm{obs}}\right)$ was found to increase with increasing temperature. Activation parameters $\left(\Delta \mathrm{H}^{\neq}, \Delta \mathrm{S}^{\neq}\right)$(Table 2$)$ were calculated by using Eyring equation. The values of activation parameters $\left(\Delta \mathrm{H}^{\ddagger}, \Delta \mathrm{S}^{\neq}\right)$are favourable for electron transfer reaction.

Basing on stoichiometry and identification of the product, the probable mechanism may be delineated as in Scheme I.

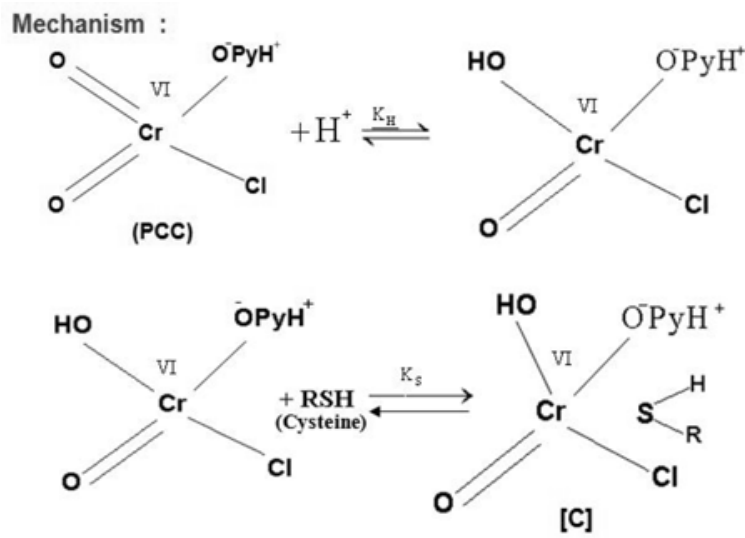

Scheme I

Table 2. Calculated values of $\mathrm{k}_{1}, \mathrm{k}_{2}$ and activation parameters using temperature range $298 \mathrm{~K}-318 \mathrm{~K}$

\begin{tabular}{|l|c|c|}
\hline Temperature $(\mathrm{T})$ & $\begin{array}{c}\text { Acid Independent } \\
\text { Path } \\
10^{2} \mathrm{k}_{1}\left(\mathrm{~s}^{-1}\right)\end{array}$ & $\begin{array}{c}\text { Acid Dependent Path } \\
\mathrm{k}_{2}\left(\mathrm{~s}^{-1}\right)\end{array}$ \\
\hline 298 & 14.86 & 9.37 \\
\hline 303 & 18.07 & 11.47 \\
\hline 308 & 22.40 & 14.07 \\
\hline 313 & 27.45 & 17.36 \\
\hline 318 & 32.79 & 20.67 \\
\hline$\Delta \mathrm{H} \neq\left(\mathrm{kJ} \mathrm{mol}^{-1}\right)$ & $30.20 \pm 0.25$ & $29.60 \pm 0.62$ \\
\hline$\Delta \mathrm{S} \neq\left(\mathrm{JK}^{-1} \mathrm{~mol}^{-1}\right)$ & $-159.65 \pm 0.83$ & $-127.09 \pm 2.17$ \\
\hline
\end{tabular}

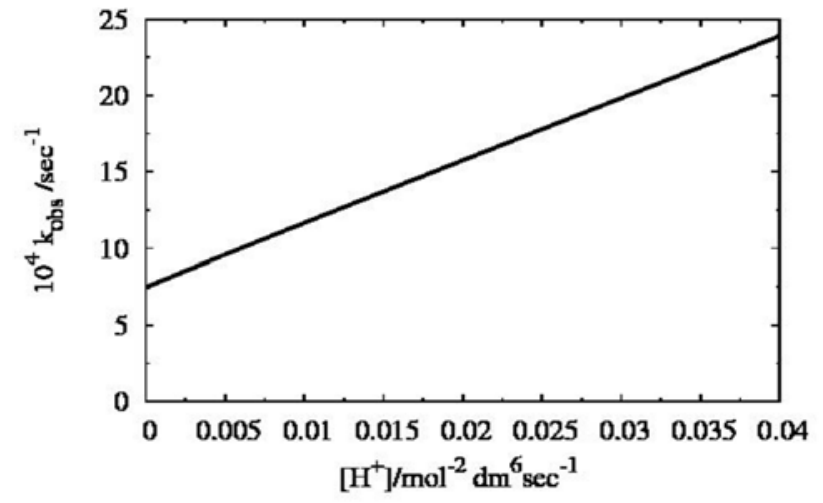

Figure 3. The plot of $\mathrm{k}_{\mathrm{obs}}$ versus $\left[\mathrm{H}^{+}\right]^{2},[\mathrm{PCC}]=5 \times 10^{4} \mathrm{~mol} \mathrm{dm}^{-3}$, [cystine] $=4 \times 10^{-3} \mathrm{~mol} \mathrm{dm}^{-3}, \mathrm{I}=0.03 \mathrm{~mol} \mathrm{dm}^{-3}$ at $303 \mathrm{~K}$

$$
\begin{aligned}
& {[\mathrm{C}] \underset{\mathrm{H}_{2} \mathrm{O}}{\stackrel{\mathrm{k}_{1}}{\longrightarrow} \mathrm{Cr}(\mathrm{V})+\mathrm{R}-\mathrm{S} .+\mathrm{H}^{+}}} \\
& {[\mathrm{C}] \underset{\mathrm{k}_{3} \mathrm{O}}{\stackrel{\mathrm{k}_{2}}{\longrightarrow}} \mathrm{Cr}(\mathrm{V})+\mathrm{R}-\mathrm{S} .+2 \mathrm{H}^{+}}
\end{aligned}
$$

Where $\mathrm{k}_{1}$ and $\mathrm{k}_{2}$ are acid independent and acid dependent paths of electron transfer reactions respectively. Rapid and kinetically unimportant steps of the product formation may probably be visualized as follows.

$2 \mathrm{Cr}(\mathrm{V})+2 \mathrm{RS} . \stackrel{\text { fast }}{\longrightarrow} 2 \mathrm{Cr}(\mathrm{IV})+\mathrm{R}-\mathrm{S}-\mathrm{S}-\mathrm{R}$

$\mathrm{Cr}(\mathrm{VI})+\mathrm{Cr}(\mathrm{IV}) \stackrel{\text { fast }}{\longrightarrow} 2 \mathrm{Cr}(\mathrm{V})$

$\mathrm{Cr}(\mathrm{V})+2 \mathrm{RSH} \stackrel{\text { fast }}{\longrightarrow} \mathrm{Cr}(\mathrm{III})+\mathrm{R}-\mathrm{S}-\mathrm{S}-\mathrm{R}+2 \mathrm{H}^{+}$

$\mathrm{Cr}$ (III) is the $\mathrm{Cr}\left(\mathrm{H}_{2} \mathrm{O}\right)_{6}{ }^{3+}$ species in aqueous acidic medium.

The rate law corresponding to the above mechanism is indicated by equation (3).

$\frac{\text { rate }}{[\mathrm{PCC}]_{0}}=\mathrm{k}_{\mathrm{ds}}=\frac{\mathrm{K}_{\mathrm{H}} \mathrm{K}_{\mathrm{S}}\left[\mathrm{H}^{+}\right][\mathrm{RSH}]\left(\mathrm{k}_{1}+\mathrm{k}_{2}\left[\mathrm{H}^{+}\right]\right)}{\left(1+\mathrm{K}_{\mathrm{S}}[\mathrm{RSH}]\right)\left(1+\mathrm{K}_{\mathrm{H}}\left[\mathrm{H}^{+}\right]\right)}$

The reaction is showing approximately first order dependence on $[\mathrm{RSH}]$.

At relatively higher $\left[\mathrm{H}^{+}\right], \mathrm{K}_{\mathrm{H}}\left[\mathrm{H}^{+}\right]>>1$ and $\mathrm{K}_{\mathrm{S}}[\mathrm{RSH}]$ $>>1$ at finite $\left[\mathrm{H}^{+}\right]$concentration, the equation (3) is reduced to equation (4)

$\frac{k_{\text {obs }}}{[\mathrm{RSH}]} \approx \mathrm{k}_{1}+\mathrm{k}_{2}[\mathrm{H}+]^{2}$ 


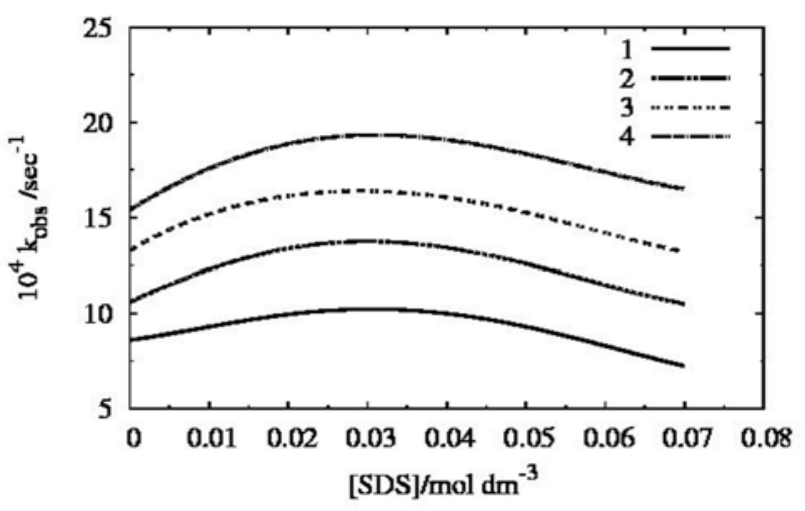

Figure 4. The plots of $\mathrm{k}_{\mathrm{obs}}$ versus [SDS] at $303 \mathrm{~K}(1), 308 \mathrm{~K}(2)$, $313 \mathrm{~K}(3), 318 \mathrm{~K}$ (4) $[\mathrm{PCC}]=5 \times 10^{-4} \mathrm{~mol} \mathrm{dm}^{-3}$, [cysteine] $=4 \times 10^{-3} \mathrm{~mol} \mathrm{dm}^{-3},\left[\mathrm{H}^{+}\right]=0.05 \mathrm{~mol} \mathrm{dm}^{-3}$

The values of $\mathrm{k}_{1}$ and $\mathrm{k}_{2}$ can be computed from plots of $\mathrm{k}_{\mathrm{obs}} /[\mathrm{RSH}]$ vs $\left[\mathrm{H}^{+}\right]^{2}$ and are listed in Table 2 . From which activation parameters are calculated.

The values of activation parameters appear to be more or less compatible with the mechanism proposed ${ }^{14,15}$.

\section{Micellar effects on electron transfer reaction}

Micellar effect on the rate of oxidation reaction between PCC and cysteine was studied using SDS, CTAB and Triton X-100. Recently Zewail and co-workers ${ }^{16}$ have indicated that the surface of the protein is similar to a micellar surface. Thus the study of such reactions in micellar medium is thought to throw more light on the details of the electron transfer reaction in the biological systems. Many researchers ${ }^{17-22}$ have also studied the micellar and reverse micellar effects on different electron transfer reactions.

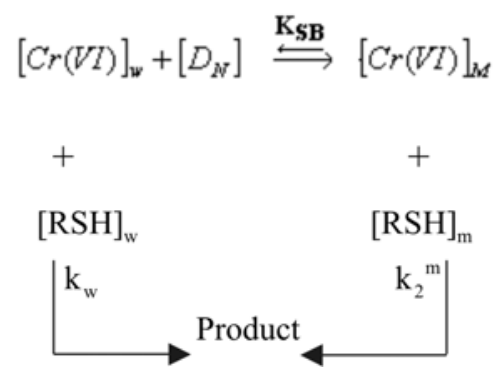

\section{Effect of SDS}

The kinetics of oxidation of cysteine with pyridinium chlorochromate was carried out in presence of SDS by changing [SDS] from 0.01 to $0.07 \mathrm{~mol} \mathrm{dm}^{-3}$ in temperature range of $303 \mathrm{~K}-318 \mathrm{~K}$. The curve (Fig. 4) shows an increase of the rate with increase of [SDS], beyond its $\mathrm{CMC}\left[\mathrm{CMC} \text { of SDS }=0.007 \mathrm{~mol} \mathrm{dm}^{-3}\right]^{23}$ it reaches a maxima at $[\mathrm{SDS}]=0.03 \mathrm{~mol} \mathrm{dm}^{-3}$, the rate of reaction decreases when [SDS] goes above $0.03 \mathrm{~mol} \mathrm{dm}^{-3}$.

The variation of the rate constant with [SDS] is explained using the assumption that the surfactant is distributed between the aqueous and micellar pseudo-phase designated as subscripts $\mathrm{w}$ and $\mathrm{m}$ respectively as shown in Scheme II ${ }^{\mathbf{2 4}}$. Scheme II

The observed first order rate constant of the overall reaction in micellar medium is given by equation (5).

$$
\begin{aligned}
& \text { Rate }=\mathrm{k}_{\mathrm{obs}} \text { [substrate] } \\
& \mathrm{k}_{\mathrm{dbs}}=\frac{\mathrm{k}_{\mathrm{w}}[\mathrm{O}]_{\mathrm{w}}+\mathrm{k}_{2}{ }^{\mathrm{m}} \mathrm{K}_{\mathrm{SB}}\left[\mathrm{D}_{\mathrm{n}}\right][\mathrm{O}]_{\mathrm{m}}}{1+\mathrm{K}_{\mathrm{SB}}\left[\mathrm{D}_{\mathrm{n}}\right]}
\end{aligned}
$$

Where $\mathrm{k}_{2}{ }^{\mathrm{m}}$ is the second order rate constant in the micellar pseudo - phase which is defined in terms of the local molarity of the oxidant.

$[\mathrm{O}]_{\mathrm{m}}$ - concentration of oxidant in micellar medium.

$\mathrm{k}_{\mathrm{w}}$ - second order rate constant in aqueous phase.

$\mathrm{K}_{\mathrm{SB}}$ - substrate binding constant.

$\mathrm{K}_{\mathrm{SB}}=\frac{\left[\mathrm{S}_{\mathrm{m}}\right]}{\left[\mathrm{S}_{\mathrm{w}}\right]\left[\mathrm{D}_{\mathrm{n}}\right]}$

Where $\left[\mathrm{D}_{\mathrm{n}}\right]=\left[\mathrm{D}_{\mathrm{T}}\right]-\mathrm{CMC}$

$\left[\mathrm{D}_{\mathrm{n}}\right]$ - micellised surfactant.

$\mathrm{S}_{\mathrm{m}}$ and $\mathrm{S}_{\mathrm{w}}$ denote substrate in the aqueous and micellar pseudo - phase respectively. As micellar pseudo-phase occupies only a small fraction (2-3)\% of total solution volume, it can be assumed that

$\mathrm{K}_{\mathrm{SB}}\left[\mathrm{D}_{\mathrm{n}}\right]<<1$

The equation (5) becomes equation (6)

$\mathrm{k}_{\mathrm{obs}}=\mathrm{k}_{\mathrm{w}}+\mathrm{k}_{2}^{\mathrm{m}} \mathrm{K}_{\mathrm{SB}}\left[\mathrm{D}_{\mathrm{n}}\right]$

Which shows a linear increase of the observed rate constant with an increase of [surfactant]. This explains the rate increase part of the curve in Fig. 4.

By assuming the rate in the micellar pseudo-phase is zero i.e. $\mathrm{k}_{2}{ }^{\mathrm{m}}=0$, equation (5) is reduced to equation (7).

$k_{\mathrm{cbs}}=\frac{\left[\mathrm{k}_{\mathrm{w}}\right]}{1+\mathrm{K}_{\mathrm{SB}}\left[\mathrm{D}_{\mathrm{n}}\right]}$

The above equation explains the decrease of the rate with an increase of the [surfactant] at [surfactant] $>0.03 \mathrm{~mol}$ $\mathrm{dm}^{-3}$. A similar micellar effect has been reported by Bunton $^{25,26}$ and Richardson ${ }^{27}$ for the oxidation of organic sulfides with peroxomonosulphate and bicarbonate-activated hydrogen peroxide respectively. This is probably due to an effect where cationic substrate and PCC are taken up by the anionic micelle on the micellar surface which assists in speeding up of the reaction. After reaching the maximum value, the rate decreases probably because the concentration of the substrate available in the aqueous phase is small.

\section{Effect of CTAB}

Rate measurement in the presence of CTAB could not be made even in a very low concentration $(0.001-0.005)$ mol dm${ }^{-3}$ due to the cloudiness of the reaction mixture.

\section{Effect of Triton X-100}

Rate measurements in the presence of neutral micelle Triton X-100 was carried out at $303 \mathrm{~K}$ with varying [Triton $\mathrm{X}-100$ ] from 0.01 to $0.08 \mathrm{~mol} \mathrm{dm}^{-3}$ at constant [oxidant] and [substrate]. The marginal retardation effect was observed up to $0.03 \mathrm{~mol} \mathrm{dm}^{-3}$ concentration of the neutral micelle probably due to structural changes of the micelle.

\section{Conclusion}

The following clear cut conclusions can be drawn from the study:

1. The kinetics of electron transfer to PCC (a Cr VI species) for a sulfur containing amino acid, cysteine [RSH], follows a pseudo-first order decay of the Cr (VI) species, a near unity dependence of rate on [RSH], a small acid 
independent and a strongly $\left[\mathrm{H}^{+}\right]^{2}$ dependent paths, are observed.

2. The derived rate law and the proposed mechanism coherently explain the kinetic observations for the product formation of disulfanyl-propanoic acid (R-S-S-R) in the reaction. The organic disulphide product is identified by FTIR. The magnitude of the activation parameters are consistence with the proposed mechanism. Negative activation entropy is indicative of the ordered transition state for the reaction. Since there is no evidence of the formation of the bridge between $\mathrm{Cr}(\mathrm{VI})$ and cysteine, it is probably outersphere electron transfer process.

3. The kinetics of the PCC - RSH reaction in acid medium is found to be strongly catalysed by SDS upto $[\mathrm{SDS}]_{0} \approx 3 \times 10^{-2} \mathrm{~mol} \mathrm{dm}^{-3}$, beyond which there is progressive retardation in the redox rate with increasing $[\mathrm{SDS}]_{0}$, this may be due to the medium effect caused by the presence of high dielectric of SDS.

4. The micellar effects on the oxidation rate in the presence of CTAB or Triton X-100 were not very pronounced.

\section{Acknowledgements}

Authors are thankful to Professor Ramakrushna Panda, Ex- Professor of Chemistry, Berhampur University for his help and co-operation.

\section{LITERATURE CITED}

1. Bilehal, D.C., Kulkarni, R. \& Nandibewoor, S.T. (2005). Comparative study of the chromium (III) catalysed oxidation of L-leucine and L-Isoleucine by alkaline Permanganate; A kinetic and mechanistic approach. J. Molecular Catalyst. 232, 21. DOI: 10.1016/j.molcata.2005.01.020.

2. Mahesh, R.T., Pandurang, D. Pol \& Sharanappa, T. Nandibewoor (2003) Kinetics and mechanism of oxidation of L- Leuncine by alkaline Diperiodatonickelate (IV) - A free radical intervention, deamonation, and decarboxylation. Chemistry and Materials science, 134, 1341-1352, DOI: 10.1007/s00706003-0608-x.

3. Abedinzadeh, Z. (2001). Sulfur-centered reactive intermediates derived from the oxidation of sulfur compounds of biological interest. Can. J. Physiol, Pharmacol, 79, 166-170. DOI: $10.1139 /$ cjpp-79-2-166.

4. Sconichc, Z.F., Wilson, G.S. \& Borchard, R. (1993). Iron-thiolate induced oxidation of methionine to methionine sulfoxide in smallk model peptides. Intramolecular catalysis by histdine. J. Bio-chim Bio-phy Acta (BBA), 1158, 307. DOI: 10.1016/0304-4165(93)90030-C.

5. Gouda, B.T. \& Vijay Lakshmi, R. (1987). Kinetics of oxdative decarboxylation of aminoacids by bromoamine-T in alkaline medium. J. Ind. Chem. Soc., 64, 40-407.

6. Annapurn, N., Kalyan Kumar, A, Vani, P. \& Rao, G. Nageswar. (2008). Kinetics of oxidation of L-cystine by pyrdinium bromochromate J. Ind. Chem. Soc., 85, 542-545.

7. Read, J.F., Bewick, S.A., Graves, C.R., Macpherson, J.M., Salah, J.C., Theriault, A. \& Wyand, A.E.H. (2000). The kinetics and mechanism of the oxidation of S-methyl-L-cystine, $L$ cysteine and $L$ - cysteine by potassium ferrate. Inorg. Chem. Acta., 303, 244. DOI: 10.1016/s0020-1693(00)00043-8.

8. Swain Trilochan and Mohanty P.(2009). Kinetics and mechanistic study on the reaction of iodo (diethylenetriamine) platinum (II) with L-cystine Aust, J. Chem., 62, 493-500. DOI: 10.1071/CH08192.

9. Corey, E.J. \& Sugges, W.J., (1975). Pyridinium chlorochromate. An efficient reagent for oxidation of primary and secondary alcohols to carbonyl compounds. Tetrahedron Lett. 2647. DOI: 10.1016/s0040-4039(00)75204-x.

10. Panigrahi, G.P. \& Mahapatra, D.D. (1980). Kinetics of oxidation of cyclopentanol, cyclohexanol, cycloheptanol and cyclooctanol by pyridinum chlorochromate(corey's Reagent) in chlorobenzene-nitro- benzene mixture. Ind. J. chem. SecB, 19, 579-582.

11. Vogel, A.I. (1989). Text Book of Quantitative Chemical Analysis (5th ed.), ELBS, Longman group UK.

12. Nakamato, K. (1997). Infrared and Raman spectra of Inorganic and coordination complex (5th ed.) John Wiley and sons Ins Publication.

13. Mohanty, S., Anand, S., Brahm, G.S. \& Mohanty, P. (2003). Kinetics and mechanism of the reaction of chromium(III) and L-ornithine in aqueous solution. J. India, Chem. Soc. 80, 810-814.

14. Ayoko, G.A., Lyun, T.F. \& Mamman, S. (1993). Kinetics and mechanism of oxidation of nitrilotriacetate by poly(pyridy)iron(III) complexes and dodecatungs-tocobaltate(III) ion-A comparative study. Ind. J. Chem. 32A, 1089-1091.

15. Kini, A.K., Farokhi, S.A. \& Nandibewoor, S.T. (2002). A comparative study of ruthenium (III) catalysed oxidation of L-Leucine and isoleucine by alkaline permanganate. A kinetics and mechanistic approach. Trans. Met. Chem. 279, 532-540. DOI: 10.1023/A: 1015641231236.

16. Pal, S.K., Peon, J., Bagchi, B., \& Zewail, A.H. (2002). Biological water: femtosecond dynamics of macromolecular hydration. J. phys. Chem., B 106, 12376-12395. DOI: 10.1021/ jp0213506.

17. Makote, R.D \& Chatterjee, C. (1999). Kinetics and mechanism of oxidation of ascorbic acid by cobalt(III) amino polycarboxylato complexes in weakly basic media. Ind.J.Chem. A 38, 783-791.

18. Sarkar, D. \& Chatterjee, D. (1996). Kinetics of desorption of proteins from the surface of protein-coated alumina by various desorbing reagents. J.colloid Interf. Sci. 178, 606-613. DIO:10.1006/jois.1996.0157.

19. Gosh, K.K. \& Tiwary, L.K. (2003). Influence of sodium bis(2-ehyl-1-hexyl) sulfosuccinate/isooctane/water microwemulsions on the hydrolysis of salicylhydroxamic acid. $J$. Mol. Liquids. 102. 183-195. DOI: PII s0167-7322(02)00061-2.

20. Sarkar, D., Khilar, K.C., Begum, G. \& Subharao, P.V. (2005). Kinetics of basic hydrolysis of tris (1,10 phenanthroline) iron(II) in triton X-100/hexanol/water reverse micelles in cyclohexane. J. Colloid. Interfer Sci. 268, 73-77. DOI: 10.1016/ j.col surfa 2005.05.062.

21. Sarkar, D. \& Subharao, P.V. (2005). Kinetics of dissociation of tris-(2,2'- bipyridyl) iron(II) in water solubilized by triton X-100 reverse micelles. J. Colloid. Interfer Sci., 288, 591-596. DOI: 10.1016/j.jcis.2005.03.026

22. Majumdar Tapas \& Mahapatra Ambikesh. (2007). Kinetics of electron transfer reaction in micellar and reverse micellar media reduction of $\left[\mathrm{Co}\left(\mathrm{NH}_{3}\right)_{5}\right] \mathrm{Cl}_{2}$ by iron(II). $J$. Colloids Surfaces. 302, 360-365. DOI: 10.1016/ j.colsufa.2007.02.059.

23. Cordes, E.H. \& Gilter, C. (1973). Progress in Bioinorganic Chemistry Kaiser, E.T, Kezdy, F. J., Wiley, New York, Bunton C.A. (1979) Solution Chemistry of Surfactants Mital K.L. \& Lindman, B. (Eds). Plenum, New York.

24. Bosco Bharathy, J.R., Ganesan, T.K., Rajkumar, E., Rajgopal, S., Manimaran, B., Rajendran, T. \& Lieh lu Kuang. (2005). Micellar effect on the electron transfer reaction of chromium(V) ion with organic sulfides. Tetrahedron, 61, 4679-4687. DOI: 10.1016/j.tet.2005.02.052.

25. Blasko, A., Bunton, C.A. \& Wright, S. (1993). Micellar charge effects on the oxidation of sulfides by periodate ion. J. phys. Chem., 97, 5435-5442. DOI: 0022-3654/93/2097$5435 \$ 04.00 / 0$.

26. Balsko, A., Bunton, C.A. \& Foroudian, H.S. (1995). Oxidation of organic sulfides in aqueous sullfobetaine micelles. J. Colloid. Interf. Sci., 175. 122-130. DOI: 10.1006/jcys.1995.1437.

27. Yao, H. \& Richardson, D.E. (2003).Bicarbonate surfoxidants micellar oxidations of aryl sulfides with bicrarbonate-activated hydrogen peroxide. J. Am Chem. Soc., 125, 6211-6221.DOI: 10.21021/ja0274756. 